\title{
Supporting Military Caregivers Options for Congress
}

- here are 5.5 million men and women in the United States today who are providing assistance for a current or former service member who has disabling injury or illness. We term these men and women military caregivers. They are our country's hidden heroes: Their support keeps veterans out of institutions and helps them live longer, higher-quality lives.

\section{Caregiving comes at a cost:}

Caregivers' mental and physical health is worse than that of noncaregivers; caregivers of post-9/11 servicemen and women ("post-9/11 caregivers") are at nearly five times greater risk of depression and report significantly worse health than noncaregivers.

\section{Military caregivers report lower} levels of satisfaction with their family and marital relationships than do non-caregivers.

\section{Caregivers attempting to juggle} caregiving with jobs miss many hours of work, resulting in personal financial strain and lost productivity for employers (the cost of lost productivity for post-9/11 caregivers is roughly $\$ 5.9$ billion per year).
All corners of society can support military caregivers to lessen their burden. The federal government plays an important part: Congress, in particular, has already created policies and authorized programs to support caregivers. But our research has identified gaps between what military caregivers need and what support is currently available to them. Here, we highlight additional ways that federal legislation can help to close these gaps.

\section{Fully fund the Lifespan Respite Care Act.}

The length of time each week a person devotes to giving care is associated with higher risks of adverse outcomes, such as depression. One way to reduce this burden is to offer temporary relief from caregiving. Respite care does this by providing short-term, substitute care. Unfortunately, respite care services for military caregivers are limited. Currently, only ten organizations (most of them private, nonprofit) offer respite services specifically to military caregivers, leaving many without access to these services.

In 2006, the Lifespan Respite Care Act was signed into law (P.L. 109-442), authorizing Congress to allocate approximately \$288 million between fiscal years 2007 and 2011 to help family caregivers access affordable and high-quality respite care. 
However, Congress only appropriated funding beginning in 2009, and since that time only $\$ 2.5$ million has been allocated annually to the program, translating into grants of approximately $\$ 200,000$ to select states. Fully funding the program would expand respite services for military caregivers, thereby reducing the burden of caregiving.

\section{Reconsider eligibility requirements for caregiver support programs.}

Eligibility for most caregiver support programs is determined by one of two factors: the age of the care recipient (most target people age 60 or older) and the relationship of the caregiver to the care recipient (most are limited to immediate family). But more than 80 percent of those who served in the military after September 11, 2001, are under age 60, making their caregivers ineligible for benefits such as the National Caregiver Family Support Program and Medicaid Home- and Community Based Services (HCBS) waivers in certain states. In addition, nearly one-third of these post-9/11 care recipients are cared for by extended family and friends, and these caregivers are ineligible for programs that are restricted to immediate family (such as the VA Caregiver Support Program). Enacting legislation to expand eligibility for these programs to include military caregivers may help fill gaps in access to support.

\section{Ensure that military caregivers have health care coverage.}

Twenty percent of pre-9/11 military caregivers and almost forty percent of post-9/11 caregivers have no health care coverage. Health care coverage is critical for caregiver well-being and helps them continue to provide care to their veterans. Currently, immediate families of veterans who were medically retired from service should have coverage through TRICARE; military caregivers enrolled in the VA Program of Comprehensive Assistance for Family Caregivers who are not otherwise insured have coverage via CHAMP-VA. Otherwise, military caregivers have the same options as civilians: getting coverage through their employers, the newly established Health Benefit Exchanges, Medicaid (for households under 133 percent of the FPL, which includes roughly 20 percent of military caregivers), or Medicare (for those over 65). Special education and outreach efforts may be required to make sure more caregivers are covered.

\section{Promote integration and coordination of programs and services.}

A centralizing body should oversee and coordinate federal efforts to support military caregivers. Currently, four agencies - the Department of Health and Human Services, the Department of Labor, the Department of Veterans Affairs, and the Department of Defense-support this population either directly or tangentially. While there is some evidence of collaboration between departments, gaps and inconsistencies in eligibility criteria and program definitions remain. Efforts to facilitate interagency coordination, such as through interagency working groups or task forces and federal Commissions, could enhance the alignment and quality of services to support military caregivers. www.rand.org

HEADQUARTERS CAMPUS

1776 Main Street

P.O. Box 2138

Santa Monica, California

90407-2138

TEL 310.393 .0411

FAX 310.393 .4818
In 2014, RAND conducted a nationally representative survey of military caregivers and a comprehensive review of programs and support resources available to address the many needs of military caregivers. The results of this study, the first of its kind, are fully documented in Ramchand R, Tanielian T, Fisher MP, Vaughan CA, Trail TE, Epley C, Voorhies P, Robbins MW, Robinson E, Ghosh-Dastidar B, Hidden Heroes: America's Military Caregivers, RR-499-TEDF, 2014 (available at www.rand.org/military-caregivers).

The RAND Corporation is a research organization that develops solutions to public policy challenges to help make communities throughout the world safer and more secure, healthier, and more prosperous. RAND is nonprofit, nonpartisan, and committed to the public interest. RAND's publications do not necessarily reflect the opinions of its research clients and sponsors.
Elizabeth Dole Foundation

CARING FOR MILITARY FAMILIES

This research was conducted by the RAND Corporation under the sponsorship of Caring for Military Families: The Elizabeth Dole Foundation. 


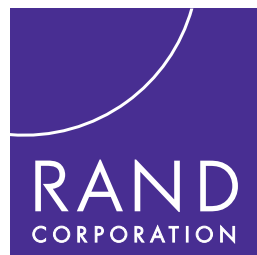

CHILDREN AND FAMILIES

EDUCATION AND THE ARTS

ENERGY AND ENVIRONMENT

HEALTH AND HEALTH CARE

INFRASTRUCTURE AND

TRANSPORTATION

INTERNATIONAL AFFAIRS

LAW AND BUSINESS

NATIONAL SECURITY

POPULATION AND AGING

PUBLIC SAFETY

SCIENCE AND TECHNOLOGY

TERRORISM AND HOMELAND SECURITY
The RAND Corporation is a nonprofit institution that helps improve policy and decisionmaking through research and analysis.

This electronic document was made available from www.rand.org as a public service of the RAND Corporation.

\section{Support RAND}

Browse Reports \& Bookstore

Make a charitable contribution

\section{For More Information}

Visit RAND at www.rand.org

Explore the RAND Corporation

View document details

\section{Research Brief}

This product is part of the RAND Corporation research brief series. RAND research briefs present policy-oriented summaries of individual published, peer-reviewed documents or of a body of published work.

\section{Limited Electronic Distribution Rights}

This document and trademark $(s)$ contained herein are protected by law as indicated in a notice appearing later in this work. This electronic representation of RAND intellectual property is provided for noncommercial use only. Unauthorized posting of RAND electronic documents to a non-RAND website is prohibited. RAND electronic documents are protected under copyright law. Permission is required from RAND to reproduce, or reuse in another form, any of our research documents for commercial use. For information on reprint and linking permissions, please see RAND Permissions. 